\title{
The role of urban habitats in the abundance of red squirrels (Sciurus vulgaris, L.) in Finland
}

\section{Jokimäki, Jukka}

2017-10

Jokimäki , J , Selonen , V , Lehikoinen , A \& Kaisanlahti-Jokimäki , M-L 2017 , ' The role of urban habitats in the abundance of red squirrels (Sciurus vulgaris, L.) in Finland ', Urban Forestry \& Urban Greening , vol. 27 , pp. 100-108 . https://doi.org/10.1016/j.ufug.2017.06.021

http://hdl.handle.net/10138/307392

https://doi.org/10.1016/j.ufug.2017.06.021

cc_by_nc_nd

acceptedVersion

Downloaded from Helda, University of Helsinki institutional repository.

This is an electronic reprint of the original article.

This reprint may differ from the original in pagination and typographic detail.

Please cite the original version. 
1 The role of urban habitats in the abundance of red squirrels (Sciurus vulgaris, L.) in

2 Finland

3

$4 \quad$ Highlights

5 - The winter abundance of red squirrels is higher in urban than in forest habitats.

$6 \quad-\quad$ Spruce crop size increase squirrel abundance.

$7 \quad$ - Feeding sites (+) and cats (-) affect squirrel abundance.

8 - Urban environments are an important alternative habitat for the declining red squirrel in $9 \quad$ Europe.

- The urbanization of squirrels can be monitored using citizen science based, large-scale winter surveys.

13 Abstract

14 Because the amount of urban areas has increased, it is important to investigate the abundance of

15 wildlife species in relation to urban environments. Analyzing the impact of urbanization on the

16 presence of forest-dwelling mammals is of interest due to the possible effects of urbanization on

17 human-wildlife relationships and urban biodiversity. The Eurasian red squirrel (Sciurus vulgaris)

18 is a declining forest species, and its occurrence in urban environments has been inadequately

19 studied. The loss and fragmentation of forests due to urbanization may be detrimental for

20 squirrels, whereas the abundant and predictable food resources and the low number of natural

21 predators in urban areas may encourage squirrels to invade towns. We used large-scale data

22 collected by volunteer bird watchers along a $950 \mathrm{~km}$ south-north gradient to study whether the

23 winter abundance of squirrels in Finland is dependent on urbanization, while controlling for 
24 effects of habitat type, food abundance (spruce cone crop; number of winter feeding sites),

25 predator abundance (northern goshawk, Accipiter gentilis; feral cat Felis catus), season and

26 latitude. We found that squirrel abundance increased with human population density, number of

27 feeding sites and spruce cone crop and decreased with latitude and season. Feral cats showed

28 weak negative connection with squirrel numbers, but there were no effect of goshawks. Relative

29 squirrel abundance was approximately twice as high in urban habitats than in forests. Artificial

30 feeding rather than a low number of predators may attract squirrels in urban environments.

31 Planting spruce trees in urban environments will also benefit squirrels. Our results indicate that

32 urban areas are an important habitat for the red squirrel even along the northern edge of their

33 distribution range, where natural forest areas are still widespread. We conclude also that a citizen

34 science -based bird survey protocol associated with mammal surveys seems to be a good large-

35 scale monitoring method to study the urbanization of squirrels.

37 Keywords: winter feeding; mammals; monitoring; predation; urbanization, citizen science

\section{1. Introduction}

40 Globally, more people now live in urban than in rural areas, and at the same time, urbanized

41 areas are increasing at an even higher rate than the urban population (UN, 2014). According to

42 Seto et al. (2011), global urban land cover will increase approximately 30 -fold by 2030 .

43 Therefore, understanding the impact of urban development on animal populations is important

44 due to the possible effects on biodiversity and human-wildlife relationships (Baker and Harris,

45 2007; Bateman and Fleming, 2012). Urbanization is one of the most extreme forms of land-use

46 alteration, and only remnants of the original habitats persist in towns. At the same time, urban 
47 areas are characterized by high levels of predictable anthropogenic food resources and human-

48 caused disturbances (e.g., traffic), milder microclimates, and an altered abundance of predators

49 (e.g., Rebele, 1994; Shochat et al., 2006; Gilbert, 2012; Francis and Chadwick, 2013;

50 Tryjanowski et al., 2015).

52 Urbanization is globally recognized as one of the main threats to biodiversity (Wilcox and 53 Murphy, 1985). An important challenge for urban ecology is to conserve species that live in 54 urban environments. In addition, most of the contacts between people and nature occur in urban 55 environments, and citizen views related to conservation are formed in urban environments 56 (Lepczyk and Warren, 2012; Shanahan et al., 2014). Urban mammals have been used by urban 57 inhabitants for aesthetic, biological and recreational purposes (Adams, 2016). Unfortunately, 58 mammalian diversity generally decreases with urbanization (McCleery, 2010). However, the 59 behavioral flexibility of individuals and increased human tolerance might favor the urbanization 60 of some species (Baker and Harris, 2007; McCleery, 2010; Lowry et al., 2012).

62 Natural environments that are modified by human activities possess challenges to native animals.

63 During recent decades, many new mammalian species, such as the European red fox (Vulpes

64 vulpes, L.; Francis and Chadwick, 2012), raccoon (Procyon lotor, L.; Adams, 2016), and

65 Eurasian badger (Meles meles, L.; Harris, 1984) have colonized urban areas. Some of them (e.g.,

66 the red fox) currently have even higher densities in urban areas than in their natural habitats

67 (Bateman and Fleming, 2012). However, only a few mammal species, such as the brown rat

68 (Rattus norvegicus, Berkenhaut) and the house mouse (Mus musculus, L.), are abundant in town 69 centers (Gilbert, 2012). 
70 Urban areas have some features, such as stable and abundant food resources and low numbers of

71 natural predators that may attract wildlife and promote, for example, the urbanization of squirrels

72 (Francis and Chadwick, 2013; Adams, 2016). Artificial feeding stations and waste offer easily

73 available food resources, especially to species feeding on seeds or having a generalist diet

74 (Adams, 2016). Although feeders in gardens are primarily designed to feed birds, they also

75 attract squirrels in urban areas, especially during the winter when food resources may become

76 scarce in forest habitats. In general, urban areas contain a lower number of larger natural

77 predators than do rural areas (Bateman and Fleming, 2012), but the abundance of medium-sized

78 carnivores might be even higher in urban environments than in more natural environments

79 (Nilon and Pais, 1997; Baker and Harris, 2007; Bateman and Fleming, 2012). However, at the

80 same time, urban squirrels may be more vulnerable to predation by domestic cats than are

81 squirrels living in rural and forest areas (Wauter et al., 1997; Shuttleworth, 2001; Magris and

82 Gurnell, 2002). It is likely that there is an optimal level of human influence at which the living

83 requirements for a species are best met or limit the level of urbanization that a species can

84 tolerate (Francis and Chadwick, 2013; Adams, 2016). However, the roles of artificial food and

85 the number of predators promoting the urbanization of squirrels are still not well known.

87 Arboreal squirrels (Sciurus spp.) are strictly dependent on forests. Therefore, they might be

88 sensitive to the forest loss caused by urbanization. However, urban areas also contain different

89 types of green spaces, such as remnant habitat patches, cemeteries, public parks and the gardens

90 of residential areas, which may be suitable living environments for many forest species (Adams,

91 2016). For example, squirrels can also inhabit fragments of forests within the urban matrix

92 (Veerboom and Abeldorf, 1990; Baker and Harris, 2007; Babińska-Werka and Żółw, 2008; 
93 Parker and Nilon, 2012; Mäkeläinen et al., 2015; Fey et al., 2016). The red squirrel (Sciurus

94 vulgaris, L.) is a native forest specialist species in most European countries, and although the

95 species still is common throughout most of its range (Gurnell and Wauters, 1999), its current

96 population is declining in many parts of Europe (Gurnell and Pepper, 1993; O 'Teangana et al.,

97 2000; Bertolino and Genovesi, 2003; Shar et al., 2008; Selonen et al., 2010). Most previous red

98 squirrel studies were conducted within forest or agricultural areas and considered the effects of

99 fragmentation on the red squirrel at a relatively small local scale. These studies indicated that red

100 squirrel occurrence and abundance increase with woodland size (Celada et al., 1994; Verbeylen

101 et al., 2003) and the area of woodland covered by coniferous trees (Veerboom and Abeldorf,

102 1990) but decrease with the distance from the nearest source area (Veerboom and Abeldorf,

103 1990; Celada et al., 1994; Verbeylen et al., 2003).

104

105 Only a few red squirrel studies have been conducted within urban areas despite the fact that the 106 species is currently quite common in urban habitats in Europe (Luniak, 2004; Babińska-Werka 107 and Żółw, 2008). One local study conducted in Brussels indicated that patch size and patch 108 quality have positive effects and that isolation has a negative effect on red squirrel patch 109 occurrence in urban areas (Verbylen et al., 2003). A study in Warsaw parks also indicated that 110 park size positively affects red squirrel abundance (Babinska-Werka and Zolow, 2008).

111 However, large-scale studies with multiple study sites and covering different habitats are needed 112 to better understand the urbanization process of red squirrel. In addition, as squirrels are 113 important dispersal agents of seeds (Steele, 2008), they may also impact on distribution of urban 114 trees. Therefore, it is important to know how urbanization influence squirrel abundance. 
116 The main aim of this study was to analyze how human density affects the winter abundance of

117 red squirrels throughout Finland. The analysis included also habitat type, natural (size of the

118 Norway spruce cone crop) or artificial (number of feeding sites) food abundance, and natural

119 (northern goshawk, Accipiter gentilis, L.) or human-associated (feral cats, Felis domesticus, L.)

120 predator abundance. In addition, we also studied whether latitude and the time of the winter

121 season affect the squirrel abundance. We conducted our study during the winter season because

122 winter is a critical period for the survival of squirrels in the northern latitudes (Selonen et al.

123 2015), and because due to the lack of leaves in the broad-leaved trees, the detectability of

124 squirrels is high during winter (Hernández, 2014). We predicted that if squirrels somehow

125 benefit from humans, then their abundance should increase with human density and should be

126 higher within urban than other habitat types. If food resources, either artificial or natural, have an

127 effect then squirrel abundance should increase with the number of feeding sites or with the size

128 of the Norway spruce cone crop. If squirrel winter abundance is dependent on predators, then

129 their abundance should change with predator abundance. Because the severity of winter

130 increases toward the north, we predicted that red squirrel abundance would decrease from the

131 south to the north. Due to winter mortality, we predicted that squirrel abundance would decrease

132 during the winter. However, the squirrel abundance could also increase towards to the spring,

133 because the visibility of squirrels increases due their early-starting mating season.

2. Methods 
140 The study was conducted in Finland along an approximately $950 \mathrm{~km}$ south-north gradient

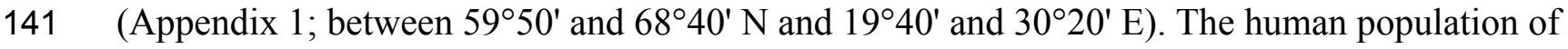

142 Finland was 5.5 million in 2014 with a mean population density of $18 / \mathrm{km}^{2}$ (Statistics Finland,

143 2015). The majority of the human population is concentrated in the southern part of the country

144 (approximately 170 inhabitants $/ \mathrm{km}^{2}$ ), whereas the population density is the lowest in the north

145 (approximately 0.2 inhabitants $/ \mathrm{km}^{2}$; Statistic Finland, 2015). Approximately $78 \%$ of the total

146 area of Finland $\left(390,906 \mathrm{~km}^{2}\right)$ is land covered (Statistics Finland, 2015), and approximately $77 \%$

147 of this is forests, $9 \%$ is agricultural areas and only $4 \%$ is built-up areas. Almost the entire country

148 belongs to the boreal taiga forest terrestrial biome, where forests are dominated by coniferous

149 trees. The study area lies within the cool boreal climate zone.

151 The study was conducted during the winter season. The average monthly temperature during 152 mid-winter in December 2014 (study year) was $-1.3^{\circ} \mathrm{C}\left(1981-2010\right.$ long-term average $\left.-3.2^{\circ} \mathrm{C}\right)$ in 153 southern Finland (Helsinki) and $-8.4^{\circ} \mathrm{C}\left(-11.7^{\circ} \mathrm{C}\right)$ in northern Finland (Sodankylä; Finnish 154 Meteorological Institute, 2014). The corresponding amounts of snow cover on the $15^{\text {th }}$ of 155 December were $4 \mathrm{~cm}$ (1981-2010 long-term average $6 \mathrm{~cm})$ in Helsinki and $32 \mathrm{~cm}$ (1981-2010 156 long-term average $36 \mathrm{~cm}$ ) in Sodankylä. The coniferous tree cone crop, the primary food of the 157 squirrels, was moderate during the studied winter (Finnish Museum of Natural History, hereafter 158 FMNH).

159 2.2. Study species

160 The red squirrel occupies the boreal and temperate areas of Eurasia and is mainly a coniferous 161 forest specialist (Shar et al., 2008). Individuals live in the same home ranges throughout the year, 
162 although they may move between habitats depending on the food situation (Wauters and Dhondt,

163 1992). In Finland, urban squirrels were first observed in the southern part of the country in the

164 cities of Helsinki and Turku in the early 1930s (Haapanen, 1999).

165

166 The main natural food of the red squirrel is seeds of coniferous trees; in Finland, these are mainly

167 Norway spruce seeds (Picea abies, Karst) (Helle, 1996; Selonen et al., 2015). The main predator

168 of the red squirrel in Finland is the northern goshawk (Selonen et al., 2010, Sulkava et al., 2014).

169 In some other countries, red foxes and feral cats are also important squirrel predators (Loss et al., 170 2013).

171

$172 \quad$ 2.3. Field data and sampling

173

174 Earlier mammal survey monitoring in Finland has been based on wildlife transect route and 175 triangle surveys conducted outside urban environments and coordinated by the Finnish Game 176 and Fisheries Institute (currently the Natural Resources Institute Finland; Lindén et al., 1996).

177 Due to the restrictions of the triangle surveys (no data from urban areas), we used data collected

178 by bird watchers during the Finnish winter bird surveys (Koskimies and Väisänen, 1991). A

179 similar approach combining avian and mammal surveys has also been used in the UK (Battersby

180 et al., 2004). Since the winter of 2014/2015, the number of mammals (individuals/10 km transect

181 route) has also been counted during the Finnish winter bird surveys.

182 The Finnish winter bird surveys consist of transect routes with an average length of

183 approximately $10 \mathrm{~km}$ (Koskimies and Väisänen, 1991). Birds and mammals are surveyed along

184 the same transect route three times per winter: early winter (1-15 November), mid-winter (25 
December to 7 January) and late winter (21 February to 6 March). The yearly surveys are

186 organized by the FMNH and are conducted by volunteer birders (610 during the studied winter

187 of 2014/2015). The participants can identify all winter birds and their calls. Thus, the observers

188 are skilled in species identification, and since the red squirrel is very easy to identify, there

189 should not be any differences between observers in ability to identify the target species of this

190 study.

192 The location of a transect route is selected freely by the volunteers, but the coordinator of the 193 surveys, the FMNH, ensures that the transect routes do not overlap. In this study, 355 transect 194 routes (279 surveyed during the early winter, 279 surveyed during the mid-winter and 258 195 surveyed during the late winter) with a total of 7,789 transect route kilometers $(2,651$ early 196 winter $\mathrm{km}, 2,669$ mid-winter $\mathrm{km}$ and 2,469 late winter $\mathrm{km}$ ) were surveyed during the winter of 197 2014/2015. The spatial distribution of the mid-winter (25 December to 7 January) survey transect 198 routes is shown in Appendix 1. The transect route is counted by walking during midday under 199 good weather and light conditions. When counting, the counter walks slowly, stops and listens, 200 and records observation notes. The survey cannot last longer than the duration of daylight in 201 mid-winter, that is, for example, approximately 4 hours in northern Finland. At each route the 202 survey time is kept about the same in all three survey periods. Note that no vehicles are used in 203 the surveys. The proportion of each habitat type along the route is estimated in advance from the 204 maps and air photos, and ground-checked in the field during the surveys. When the route runs 205 along a border of two habitats, the length is halved between them. Habitats along the route are 206 classified into eight categories within an accuracy of 100 meters: (a) dumping ground or fur farm 207 (data in this study: $11 \mathrm{~km}$ of transect routes); b) urban settlement (construction zones, town 
208 centers, private homes with gardens, urban parks, etc.; $2003 \mathrm{~km}$ ); c) rural settlement (widely

209 dispersed buildings within agricultural landscapes; $1233 \mathrm{~km})$; d) arable land (897 km); e) forest

$210(2812 \mathrm{~km})$; f) clear-cut area or stand of saplings (262 km); g) reed bed or shore scrub (150 km);

211 and h) other (including also over-flying individuals; $421 \mathrm{~km}$ ). Thus, the distribution of transect

212 routes is somewhat concentrated near human settlements, but the sample size outside these areas

213 is also substantial (e.g., $>2800 \mathrm{~km}$ in forests). All observed squirrels, northern goshawks and

214 feral cats (either seen or heard at an unlimited distance; note that no snow tracks are included in

215 the data) are placed in one of the eight habitat categories in the field. For example, one route may

216 consist 8000 meters of urban and 2000 meters of forest habitat including four squirrels observed

217 in urban and one squirrel in forest habitat type. The observers also count the number of winter

218 feeding sites in each of the above-mentioned habitats and estimate the size of the Norway spruce

219 cone crop in trees along the transect routes during the each survey (six cone abundance

220 categories; from $1=$ no cones to $6=$ very abundant cone availability; note that only the fresh

221 cones are used to do this estimation). Because the methods do not allow density estimates, an

222 index of relative abundance (individuals $/ 10 \mathrm{~km}$ transect route) is used in this study. A more

223 detailed description of the survey protocol is given elsewhere (see Koskimies and Väisänen,

224 1991, Lehikoinen et al., 2013; Fraixedas et al., 2015). 
230 The human densities (inhabitants $/ \mathrm{km}^{2}$ ) around the survey transect routes were estimated using

231 the coordinates of the transect route and the human density register of Statistics Finland provided

232 by the IT Center of Science (https://sui.csc.fi/applications/paituli(PalTuli/index-html). We placed

233 a rectangle around the survey transect route based on the southernmost, northernmost,

234 easternmost and westernmost location of the transect route. Based on the human density register,

235 we estimated how many people live inside this rectangle and used it as a proxy for the human

236 density around the survey transect route. This work was conducted using the ArcMap 10.3.1

237 software (Redlands, California, USA).

238

\subsection{Statistical analyses}

240

241 We conducted analyses at two scales. In the first analysis, we investigated which factors

242 influence transect route-specific squirrel numbers at the large landscape level using transect

243 route-specific variable values. In the second analysis, we used more detailed data within the

244 transect routes to investigate the habitat selection of squirrels using habitat-specific transect route

245 sections. The first analysis was only possible using 285 routes where the exact location of the

246 route was available and we were thus possible to calculate the human densities around the route.

247 In the second analyses all 355 routes were included.

249 First, we evaluated the transect route-specific values of squirrel number using generalized mixed 250 effect models, where the transect route-specific number of observed squirrels was explained 251 using the length of the transect route, the survey season (categorical variable), the latitude and

252 longitude of the transect route, the linear and quadratic effects of human density (log 
253 transformed), and the abundance of winter feeding sites (log transformed) and predators

254 (goshawks and feral cats). The length of the transect route accounts for the fact that the lengths

255 of the transects vary between routes. The quadratic effect of human density accounts for the

256 possibility that squirrel numbers can experience, e.g., a peak or drop in areas of average human

257 density. We also included an interaction term between latitude and human density as well as

258 human density and abundance of feeding sites in the analyses. These can take into account that

259 impact of human density can depend on latitude and feeding may affect squirrel numbers

260 differently in areas of high and low human densities. The transect route ID was used as a random

261 factor because most of the transect routes were surveyed during all three winter sub-seasons.

262 Length of the route, coordinates and census season were included in all the models, but

263 otherwise we used all model combinations of used variables. Altogether, this produced 56

264 different model combinations. The length of the transect route (continuous variable), latitude

265 (continuous variable), longitude (continuous variable) and survey season (categorical factor

266 variable) were included in all models and thus formed the base model. The numbers of predators

267 (goshawks and cats) and winter feeding sites were transformed into relative abundances (number

268 of animals or feeders per 10 survey kilometer).

270 Second, we investigated the habitat-specific values of squirrel numbers using generalized mixed

271 effect models. For this analysis, we split the transect routes into sections based on eight different

272 habitat categories (see section 2.3. Field data). Habitat was used as eight categorical factor

273 variable and forest habitat was used as a reference category. In this analysis, the squirrel numbers

274 were explained by the length of the transect route section (continuous variable), habitat type of

275 this transect route section, survey season (categorical factor variable), latitude of the transect 
276 route (continuous variable), abundance of winter feeding sites in the transect route section

277 (continuous variable) and relative abundance of spruce cones along the full transect route

278 (continuous variable). Like in the first analysis, the ID of the transect route was used as a random

279 factor in the analysis. The length of the transect route section, latitude and census season were

280 included in all models and thus formed the base model. In this analysis, the habitat-specific

281 squirrel abundance was compared to that in the forested areas. In addition, we tested whether

282 detection probability might be season dependent between natural and urban areas by adding an

283 interaction between season and habitat. Altogether, we built 9 different model combinations.

285 Both analyses were conducted using the stepwise procedure. First, using the full model, we

286 measured which distribution models, (i) Poisson, (ii) zero-inflated Poisson, (iii) negative

287 binomial or (iv) zero-inflated negative binomial distribution, best fit the data. Second, among

288 these four alternatives, we used the best of the top-ranked distributions in the full set of candidate 289 models. We used the Akaike information criterion (AIC hereafter) to perform model selection

290 (Burnham and Anderson, 2002).

291

292 All analyses were conducted in R version 3.2.2 (R Development Core Team, 2013) and models

293 were fitted using glmmadmb-package. When analyzing spatial data, it is possible that

294 autocorrelation of variables may bias the results. The potential spatial autocorrelation of

295 residuals of the best model was investigated by using the ncf-package in R. No spatial

296 autocorrelation was found from the residuals of the best models. Also multicollinearity among

297 explanatory variables may have confounding effects on results. In our case, there was no strong

298 correlation between the explanatory variables. The maximum Pearson's correlation coefficient 
was always below 0.5 (Booth et al. 1994), except in the case of human densities and quadratic

300 effect of human densities. In this case only one of these two variables were used at time.

\section{Results}

Altogether, 1781 squirrels were observed along the transect routes across all seasons (early winter 785, mid-winter 448, late winter 548). The relative squirrel abundance, feeding sites, goshawks and cats in the different habitats are shown in Table 1. In general, the relative squirrel

307 abundance was lower in forest (1.43 individuals/10 $\mathrm{km}$ transect route) than in rural (4.00

308 individuals $/ 10 \mathrm{~km}$ transect route) or urban (4.24 individuals/10 km transect route) habitats. In 309 addition, the number of feeding sites per $10 \mathrm{~km}$ transect route was lower in forest $(0.72)$ than in 310 rural (19.46) or urban (18.26) habitats. The relative abundance of northern goshawks in urban 311 areas (0.57 individuals/10 $\mathrm{km}$ transect route) was approximately twice as high as in forest $(0.27)$

312 or rural (0.22) habitats. Approximately twice the number of feral cats was observed in rural (0.66

313 individuals $/ 10 \mathrm{~km}$ transect route) than in urban habitats $(0.30)$, whereas only one cat was

314 observed in the forest habitats (Table 1).

316 In the transect route analyses, the zero-inflated negative binomial models were top-ranked in the 317 first model selection step (results not shown). In the second step of the transect route-specific 318 analysis, the top-ranked model included the length of the transect route, latitude, longitude, 319 season, abundance of feral cats, quadratic effect of human density and abundance of feeding 320 places and their interaction. The other model within $2 \Delta \mathrm{AIC}$ of the best model included these 
321 same variables, but also interaction between quadratic human density and latitude (Table 2).

322 However, since this interaction was not significant this variable can be considered as

323 uninformative parameter (sensu Arnold 2010) and only the top ranked model was investigated

324 later on. The number of squirrels increased with the increasing length of a transect route, 325 quadratic effect of human density (Fig. 1a) and abundance of feeding sites (Fig 1b) and

326 decreased with increasing latitude (Table 3). The significant negative interaction between 327 quadratic human population and abundance of feeding sites suggest that feeding increased 328 squirrel numbers more in areas where there was lower human densities (Table 3). There was also 329 tendency that abundance of feral cats decreased squirrel numbers (Table 3). The relative squirrel 330 abundance was significantly lower during the mid-winter and late winter counts than the early 331 winter counts. The abundances of goshawks was not significantly associated with squirrel 332 numbers (Table 2).

334 In the habitat-specific analyses, the negative binomial models were top-ranked in the first model

335 selection step (results not shown). In the second step of the habitat-specific analysis, the full 336 model was clearly the best model (Table 4). This top-ranked model included the length of the 337 transect route, latitude, season, habitat, number of feeding sites and spruce cone crop. Based on 338 the top-ranked model coefficients, transect route length, most habitat types, abundances of 339 feeders and the size of the Norway spruce cone crop and seasons differed significantly from zero 340 (Table 5). The highest abundances were observed in urban and rural settlements, where the 341 relative squirrel abundances (approximately 4 squirrels per $10 \mathrm{~km}$ transect route) were 342 significantly higher than those in forests (approximately 2 squirrels per $10 \mathrm{~km}$ transect route) or 343 other habitats (0-1 squirrels per $10 \mathrm{~km}$ transect route; Fig. 2a). In contrast, the relative abundance 
344 of red squirrels in arable land and reed beds was significantly lower than that in forests (Fig. 2a,

345 Table 5). In addition, the relative squirrel abundance increased with increasing transect length,

346 number of feeders and number of spruce cones (Table 5; Fig. 2b). As in the transect route-

347 specific analysis, the relative squirrel abundance decreased from early winter to the mid-winter

348 and late winter (Table 5).

\section{Discussion}

Our analysis indicated that red squirrel abundance increased with human density. The relationship between squirrel abundance and human density was nonlinear, as squirrel abundance

354 increased more rapidly in areas with the highest human densities. Our habitat-specific analysis

355 further showed that the squirrel abundance was significantly higher in urban and rural

356 settlements than in other habitats, such as forests. These results suggest that the wintering red

357 squirrels benefits from urbanization.

359 We found a higher red squirrel abundance in urban and rural settlements than in forest habitats.

360 Red squirrels inhabited urban habitats similarly in different parts of Finland, as indicated by the 361 non-significant interaction term between latitude and human density. Therefore, the urbanization 362 of the red squirrel in Finland appears to be in a phase in which no geographical difference in the 363 level of urbanization can be seen. It has been concluded that the spread of urbanization in 364 different geographical regions depends on whether urbanization in different cities occurs 365 independently or through the migration of urbanized individuals from one city to another (Evans 366 et al., 2009, 2010, Fey et al., 2015). In the case of the red squirrel in Finland, the process of how 
367 different cities have become urbanized remains unknown, but it is known that the arrival of

368 squirrels to urban areas began in the southwestern cities of Finland approximately 90 years ago

369 (Haapanen, 1999). The population dynamics of urbanized squirrels remain unclear in our study.

370 However, the squirrels abundances observed in this study should reflect the local population size,

371 because dispersal distances of red squirrels are short, usually 1-2 km, although occasionally even

372 10-20 km moved distances can be observed (Selonen and Hanski, 2015). In other words,

373 squirrels in our study areas likely do not make migrations between urban and rural areas

374 (Selonen \& Hanski 2015, Fey et al. 2016) but the abundances observed here reflect the local

375 population size. In Warsaw, Poland, it is observed that red squirrel abundance has increased

376 threefold from 1956 to 2000 in the urban areas (Babinska-Werka and Zolow, 2008). In our study,

377 squirrel abundance decreased toward the north (both in rural and urban habitats), a trend that

378 could be expected because the productivity of forests declines and winter harshness increases

379 toward the north.

380

381 Squirrel abundance was greatest in areas with the highest human population density. Because we 382 evaluated human density at a relatively coarse scale, we cannot compare squirrel abundance, for 383 example, between town centers and suburban areas. In general, the amount of woodlands 384 decreases with increasing human density, but parks with trees are common in Finland, even in 385 town centers. Red squirrels may survive quite well within these urban areas (Fey et al., 2016).

386 However, it is fair to suppose that squirrel abundance is higher in suburban areas than in more 387 urbanized areas because winter feeding is more common in these residential private-house areas 388 than in urban core areas (Väisänen, 1999). 
389 One factor related to the high squirrel abundance observed in urban areas could be winter

390 feeding. Our study indicated that squirrel abundance increased with the number of winter feeding

391 sites. Many mammal species living in urban areas use feeding sites. According to the results of

392 the Finnish winter feeding site study program 1988/89-1998/99, almost all (about 40) Finnish

393 winter-active mammal species are detected in the feeding sites $(n=455$ sites $)$, and the red

394 squirrel is the most common mammalian species occurring at $71 \%$ of these sites (Väisänen,

395 1999). Our results indirectly indicated that squirrels are more able to utilize feeding sites in areas

396 with a lower human density. Therefore, putting artificial feeders in natural areas may be a good

397 management option. Supplemental food provided by humans is one possible reason why

398 squirrels have urbanized. Likely because of artificial feeding, escape distances of squirrels have

399 declined, and they have become tame (Luniak, 2004; Parker, and Nilon, 2012; Uchida et al.,

400 2015). In addition, behavioral flexibility may be one reason for the success of some mammal

401 species, such as squirrels, in urban environments (Bateman and Fleming, 2014).

402

403 Previous studies have indicated that winter feeding may be beneficial, e.g., for the grey squirrel

404 (e.g., Bonnington et al., 2014). Winter feeding and anthropogenic waste offer great and

405 predictable food resources for animals, especially during the winter period and years when the

406 main food sources of squirrels, i.e., the seeds of conifers, are scarce. For example, Verbeylen et

407 al. (2003) found that patches with supplementary feeding had a higher probability of being

408 occupied by the red squirrel. Winter feeding has apparently helped squirrels adjust to urban and

409 suburban habitats. Feeding wildlife is widespread and have a many impacts on the wildlife

410 (Orams, 2002). While many previous studies have suggested artificial feeding have positive

411 effects especially on birds (Siriwardena et al., 2007; Harrison et al., 2009), some other papers 
412 have also indicated its risk (Jones et al., 2008). Currently, negative aspects of supplemental

413 feeding have been actively discussed in urban areas (Galbraith et al., 2015), for instance, animals

414 aggregated by artificial feeding could be more vulnerable to pathogen transmission (Bradley, and

415 Altizer 2006). Also, the possibility of ecological traps may be worth to consider (Robertson et

416 al., 2013; Hanmer et al., 2017). However, there are also psychological benefits of the wildlife for

417 the humans, enhanced by artificial feeding (Orams, 2002).

419 Our results indicated that squirrel abundance increased with the spruce cone crop. This is not a

420 surprising result since spruce seeds are main food for the red squirrel (Gurnell and Wauters,

421 1999; Selonen et al., 2015). Favoring spruce trees will likely increase the living possibilities of

422 squirrels in urban environments. We note that our study year had a moderate spruce cone crop;

423 thus, crop failure did not push animals to feeders in urban areas. Bowers and Breland (1996) and

424 Petty et al. (2003) also indicated that food availability (either artificial food or conifer seeds) is

425 the main factor limiting the number of tree squirrels. However, because previous studies have

426 indicated that the squirrel numbers in winter follow spruce cone production in Finland (Selonen

427 et al., 2015), multi-year surveys are needed to study the role of artificial feeding for squirrels in a

428 more detailed way. For example, it may be that feeding sites are even more important for

429 squirrels during poor cone years than during those years with average cone production, as in our

430 case. However, Reher et al. (2016) found that food provision in semi-urban habitat had positive

431 effect on red squirrels also in years when natural food sources were available. One factor that

432 might promote the urbanization of squirrels is the so- called "urban heat island" phenomenon

433 (Adams, 2016). Animals living in warmer conditions may survive with less energy than 
434 individuals occupying in colder environments. Unfortunately, we had no data to analyze this topic, but it might be a relevant topic for further study.

437 Earlier studies have suggested that predator presence, but not food supplementation, affects red 438 squirrel abundances in forest habitats during winter (Selonen et al., 2016). Some studies have 439 indicated that urban areas have few predators, which may support the urbanization of some 440 species (Bateman and Fleming, 2012). However, in our case, the main squirrel predator in our

441 areas, the goshawk, was more abundant in human-dominated areas than in forest habitats. This

442 result is affect by the fact that many goshawks (especially juveniles) migrate to cities in winter in

443 Finland. In any case, urban environments can no longer be considered predator-free areas for red

444 squirrels. Similar to our study, other studies have also indicated that predators, either natural or 445 human-associated, have no role in relative squirrel abundance (Bateman and Breland, 1996;

446 Petty et al. 2003). Our results indicate that amount of feral cats can limit squirrel numbers. Also 447 many earlier studies have indicated the harmful impact of the non-native cat predation on native 448 animal fauna in general (Moseby et al., 2015; Adams, 2016) and also on squirrels (Baker et al., 449 2005). Limiting cat numbers could help squirrel populations in urban and rural areas.

451 We must stress that we were not able to control for the detectability of squirrels in different 452 seasons (Hernández, 2014) and habitats (see e.g. Amori et al., 2011), and this may have partly 453 affected our results. For example, detectability of squirrels has been reported to be higher in late 454 autumn and winter than summer or spring because dense foliage decreased the detectability of 455 squirrels during summer (Hernández, 2014). We detected the lowest relative squirrel abundance 456 during the mid-winter, indicating an increase towards the end of winter. Towards to early-spring 
457 (i.e. late winter season in our case) day length becomes longer and the activity of squires would 458 also increase partly due to mating activities. The detectability of the red squirrel may be either

459 higher in human-dominated habitats than in more natural habitats due to the attraction to 460 artificial feeders, less hiding places (e.g. tree cavities, dense woods) or changing individual 461 personalities (bolder in urban habitat; Lowry et al., 2013), or the detectability of squirrels may 462 also be low in urban environments because buildings decrease detectability of squirrels (our 463 personal observations). However, the detectability of squirrels may be higher in open rural areas 464 than in more closed forest and urban habitats, which may partly explain the high squirrel 465 abundance in the rural landscape. In any case, supporting our results, previous studies have 466 indicated that squirrel densities are lower in rural than in urban environments (Babińska-Werka 467 and Żółw, 2008; Dozières et al., 2012). In addition, we tested whether detection probability 468 might be season dependent in urban areas compared to more natural areas, by testing the effect 469 of interaction between season and human population size. This interaction was not significant.

471 We used mammalian data collected by the volunteer bird watchers during their winter bird 472 surveys. This citizen science-based survey and monitoring method has several benefits. First, the 473 winter bird transect routes also cover urban environments, which are lacking in Finnish wildlife 474 monitoring efforts. Second, a large number of bird watchers can collect mammalian data from 475 large areas. The use of volunteer-based annual monitoring enables the production of long-term 476 datasets of the distribution and population trends of many mammalian species (Battersby and 477 Greenwood, 2004). In addition, winter surveys are a good method for monitoring squirrel 478 abundance because squirrels are easiest to detect in winter (Babińska-Werka and Żółw, 2008). 


\section{Conclusions}

481 Our results indicate that the level of urbanization is high among European red squirrel

482 populations (Verbeylen et al., 2003, Babińska-Werka and Żółw, 2008; Dozières et al., 2012;

483 Rézouki et al., 2014). Based on our data, red squirrels use urban areas even along the northern

484 edge of their distribution range, where natural forest areas are still widespread. During winter,

485 more red squirrels were detected in urban than in forest habitats. In the light of observations that

486 red squirrels in forests and rural areas are declining in many European countries (Shar, 2008;

487 Selonen et al., 2010), urbanized areas may provide an important alternative habitat for the red 488 squirrel. Consequences of urban development are not always disadvantages for native species.

489 Our study indicated that human presence may have positive effect on red squirrels, for example 490 winter feeding sites attract squirrels within urban environments and thereafter offer more wildlife 491 contact for urbanites and suburbanites. Increasing amount of spruce trees in urban environments 492 will increase food resources and offer hiding places for the squirrels. Citizen science has become 493 more and more popular for ecological and evolutionary studies (e.g. Newman et al., 2003;

494 Silvertown, 2009), unfortunately very few studies have been conducted in mammals. Our study 495 show how citizen science data can be used for monitoring mammal species in urban areas.

497 Acknowledgements

498 We thank all of the volunteers who participated in this nationwide survey; without their help, this

499 large-scale work would not have been possible. AL was funded by the Academy of Finland 500 (grant 275606). Ministry of Environment has supported winter bird censuses in Finland. The 501 language usage in this article was checked by the Wiley Editing Service. 


\section{References}

Adams, C.E., 2016. Urban Wildlife Management. $3^{\text {rd }}$ Edition, Taylor and Francis, New York. Amori, G., Mortelliti, A., Guidarelli, G., Schiavano, A., Luiselli, L. 2012. Detectability of the European red squirrel (Sciurus vulgaris) in a Mediterranean area. Rendiconti Lincei, 23, 203206.

Arnold, T. W., 2010: Uninformative parameters and model selection using Akaike's Information Criterion. Journal of Wildlife Management 74: 1175-1178.

Babińska-Werka, J. and Żółw, M (2008). Urban populations of the red squirrel (Sciurus vulgaris) in Warsaw. Annales Zoologici Fennici 45, 270-276.

Baker, P. J., Bentley, A. J., Ansell, R. J.,Harris, S. 2005. Impact of predation by domestic cats Felis catus in an urban area. Mammal Review, 35, 302-312.

Backer, P.J., Harris, S., 2007. Urban mammals: what does the future hold? An analysis of the factors affecting patterns of use of residential gardens in Great Britain. Mammal Review 37, 297-315.

Bateman, P. W., Fleming, P.A., 2012. Big city life: carnivores in urban environments. Journal of Zoology 287, 1-23.

Bateman, P.W., Fleming, P.A., 2014. Does human pedestrian behaviour influence risk assessment in a successful mammal urban adapter? Journal of Zoology 294, 93-98.

Battersby, J E., Greenwood, J.J., 2004. Monitoring terrestrial mammals in the UK: past, present and future, using lessons from the bird world. Mammal Review 34, 3-29.

Becker, D. J., Streicker, D. G., Altizer, S., 2015. Linking anthropogenic resources to wildlife-pathogen dynamics: a review and meta-analysis. Ecology Letters, 18, 483-495. Bertolino, S., Genovesi, P., 2003. Spread and attempted eradication of the grey squirrel (Sciurus carolinensis) in Italy, and consequences for the red squirrel (Sciurus vulgaris) in Eurasia. Biological Conservation 109, 351-358.

Bonnington, C., Gaston, K.J., Evans, K.L., 2014. Squirrels in suburbia: influence of urbanisation on the occurrence and distribution of a common exotic mammal. Urban Ecosystems 17, 533-546.

Booth, G., Niccolucci, M., Schuster, E, 1994. Identifying proxy sets in multiple linear regression: an aid to better coefficient interpretation. U.S. Department of Agriculture Forest Service, Washington, D.C.

Bowers, M., Breland, B., 1996. Foraging of gray squirrels on an urban-rural gradient: use of the GUD to assess anthropogenic impact. Ecological Applications 6, 1135-1142.

Burnham, K.P., Anderson, D.R., 2002. Model selection and multimodel inference. Springer, New York.

Celada, C., Bogliani, G., Gariboldi, A.,Maracci, A., 1994. Occupancy of isolated woodlots by the red squirrel Sciurus vulgaris L. in Italy. Biological Conservation 69, 177-183.

Dozières. A., Chapuis. J.-L., Thibault. S., Baudry. E., 2012. Genetic structure of the French red squirrel populations: implication for conservation. PloS ONE 7: e47607. doi: 10.1371/journal.pone.0047607

Evans, K.L., Gaston, K.J., Frantz, A.C., Simeoni, M., Sharp, S.P., McGowan, A., Dawson, D.A., Walasz, K., Partecke, J., Burke, T., Hatchwell, B. J., 2009. Independent colonization of multiple urban centres by a formerly forest specialist bird species. Proceedings of the Royal Society B-Biological Sciences 276, 2403-2410. 
Evans, K.L., Hatchwell, B.J., Parnell, M., Gaston, K. J.,2010. A conceptual framework for the colonisation of urban areas: the blackbird Turdus merula as a case study. Biological Reviews 85, 643-667.

Fey, K, Hämäläinen, S, Selonen, V., 2016. Roads are no barrier for dispersing red squirrels in an urban environment. Behavioral Ecology 27, 741-747.

Fey, K., Vuorisalo, T., Lehikoinen, A., Selonen V., 2015. Urbanization of the wood pigeon (Columba palumbus) in Finland. Landscape and Urban Planning 134, 188-194.

Finnish Meteorological Insitute, 2014. Climate Statistics Finland 2014 and 2015. Helsinki. Forman, R.T., Alexander, L.E., 1998. Roads and their major ecological effects. Annual review of ecology and systematics 29, 207-231,

Fraixedas Nuñez, S., Lehikoinen, A., Lindén, A., 2015. Impact of climate and land change on wintering bird populations in Finland. Journal of Avian Biology 46, 63-72.

Francis, R.A., Chadwick, M.A., 2012. What makes a species synurbic. Applied Geography 32, 1200-1216.

Francis, R.A., Chadwick, M.A., 2013. Urban ecosystems: understanding the human environment. Routledge, Cornwall.

Galbraith, J. A., Beggs, J. R., Jones, D. N., Stanley, M. C., 2015. Supplementary feeding restructures urban bird communities. Proceedings of the National Academy of Sciences, 112(20), E2648-E2657.

Gilbert, O., 2012. The ecology of urban habitats. Springer Science and Business Media.

Gurnell, L.J., Pepper, H., 1993. A critical look at conserving the British red squirrel Sciurus vulgaris. Mammal Review 23, 127-137.

Gurnell, J., Wauters, L., 1999. Sciurus vulgaris. In: A. J. Mitchell-Jones, G. Amori, W. Bogdanowicz, B., Kryštufek, P.J.H., Reijnders, F., Spitzenberger, M., Stubbe, J. B.M., Thissen, V., Vohralík, J., Zima (Eds), The Atlas of European Mammals (180-181). Academic Press, London.

Haapanen, E., 1999. Menneisyyden Helsingin eläimet: pääkaupungin nisäkkäät, matelijat ja sammakkoeläimet arkistolähteissä vuosina 1850-1980. Helsingin kaupungin

ympäristökeskuksen julkaisuja. 4. (in Finnish)

Hanmer, H. J., Thomas, R. L., Fellowes, M. D. 2017. Provision of supplementary food for wild birds may increase the risk of local nest predation. Ibis, 159, 158-167.

Harris, S., 1984. Ecology of urban badgers Meles meles: distribution in Britain and habitat selection, persecution, food and damage in the City of Bristol. Biological Conservation 28, 349-375.

Harrison, T. J., Smith, J. A., Martin, G. R., Chamberlain, D. E., Bearhop, S., Robb, G. N., Reynolds, S. J., 2010. Does food supplementation really enhance productivity of breeding birds?. Oecologia, 164, 311-320.

Helle, P., 1996. Orava. In: Lindén, H., M. Hario., Wikman, M. (Eds.), Riistan jäljille. Oy

Edita Ab, Helsinki, pp. 26-29. (in Finnish)

Hernández, Á., 2014. Seasonal habitat use in Eurasian red squirrels residing in Iberian

hedgerows. Hystrix, the Italian Journal of Mammalogy, 25, 95-100.

Jones, D. N., James Reynolds, S., 2008. Feeding birds in our towns and cities: a global research opportunity. Journal of Avian Biology, 39, 265-271.

Koskimies, P.,Väisänen, R.A., 1991. Monitoring Bird Populations - A Manual of Methods Applied in Finland. - Zoological Museum, Finnish Museum of Natural History, University of Helsinki, Helsinki. Available at: http://www.luomus.fi/en/methods-bird-monitoring 
Lehikoinen, A., Lehikoinen, E., Valkama, J., Väisänen, R. A., Isomursu, M., 2013. Effects of Trichomonas-epidemics on Finnish greenfinch and chaffinch populations. Ibis 155, 357-366. Lepczyk, C.A., Warren, P.S. (Eds.), 2012. Urban bird ecology and conservation (Vol. 45). University of California Press, London

Lindén, H., Hario, M., Wikman, M., (Eds.), 1996. Riistan jäljille. Oy Edita Ab, Helsinki. (in Finnish)

Loss, S. R., Will, T., Marra, P.P., 2013. The impact of free-ranging domestic cats on wildlife of the United States. Nature communications 4, 1396.

Lowry, H., Lill, A., Wong, B., 2013. Behavioural responses of wildlife to urban environments. Biological Reviews 88, 537-549.

Luniak, M., 2004. Synurbanization - adaptation of animal wildlife to urban development. In: Shaw, WW, LK Harris, Vandruff, L. (Eds.), Proceedings of the 4 th International Urban Wildlife Symposium. University of Arizona. Tucson, Arizona, pp. 50-55. Magris, L., Gurnell, J., 2002. Population ecology of the red squirrel (Sciurus vulgaris) in a fragmented woodland ecosystem on the Island of Jersey, Channel Islands. Journal of Zoology 256, 99-112.

Moseby, K. E., Peacock, D. E., Read, J. L. 2015. Catastrophic cat predation: a call for predator profiling in wildlife protection programs. Biological Conservation, 191, 331-340. Mäkeläinen, S., Schrader, M.,Hanski, I.K., 2015. Factors explaining the occurrence of the Siberian flying squirrel in urban forest landscape. Urban Ecosystems 18, 223-238.

McCleerly, R., 2010. Urban Mammals. In: Aitkenhead, J.,Volder, A. (Eds.), Urban Ecosystem Ecoloogy, Agronomy Monographs 55. American Society of Agronomy, Crop Science of America, Soil Science of America, Madison. pp. 87-102.

Newman, G., Wiggins, A., Crall, A., Graham, E., Newman, S., Crowston, K., 2012. The future of citizen science: emerging technologies and shifting paradigms. Frontiers in Ecology and the Environment, 10, 298-304.

Nilon C.H., Pais, R.C., 1997 Terrestrial vertebrates in urban ecosystems: developing hypotheses for the Gwynns Falls Watershed in Baltimore, Maryland. Urban Ecosystems 1, $247-57$.

Orams, M. B., 2002. Feeding wildlife as a tourism attraction: a review of issues and impacts. Tourism management, 23, 281-293.

O'Teangana, D.O., Reilly, S., Montgomery, W I., Rochford, J., 2000. Distribution and status of the red squirrel (Sciurus vulgaris) and grey squirrel (Sciurus carolinensis) in Ireland. Mammal Review 30, 45-56.

Parker, T.S., Nilon, C.H., 2012. Urban landscape characteristics correlated with the synurbization of wildlife. Landscape and Urban Planning 106, 316-325.

Petty, S.J., Lurz, P.W.W., Rushton, S.P., 2003. Predation of red squirrels by northern goshawks in a conifer forest in northern England: can this limit squirrel numbers and create a conservation dilemma? Biological Conservation 111, 105-114.

R Development Core Team, 2013. R: A language and environment for statistical computing. Version 3.2.2.

Rebele, F., 1994. Urban ecology and special features of urban ecosystems. Global ecology and biogeography letters 4, 173-187.

Reher, S., Dausmann, K. H., Warnecke, L., Turner, J. M. (2016). Food availability affects habitat use of Eurasian red squirrels (Sciurus vulgaris) in a semi-urban environment. Journal of Mammalogy, gyw105. 
Rézouki, C., Dozières, A., Le Cœur, C., Thibault, S., Pisanu, B., Chapuis, J.L., Baudry, E., 2014. A Viable Population of the European Red Squirrel in an Urban Park. PloS one, 9(8), e105111. doi: 10.1371/journal.pone.0105111.

Robertson, B. A., Rehage, J. S., Sih, A., 2013. Ecological novelty and the emergence of evolutionary traps. Trends in Ecology \& Evolution, 28, 552-560.

Selonen, V., Sulkava, P., Sulkava, R., Sulkava, S., Korpimäki, E., 2010. Decline of flying and red squirrels in boreal forests revealed by long-term diet analyses of avian predators. Animal Conservation 13, 579-585.

Selonen, V., Hanski, I.K., 2015. Occurrence and dispersal of the red squirrel and the Siberian flying squirrel in fragmented landscapes. In: Shuttleworth, C. M., Lurz, P. W., Hayward, M. W., Red Squirrels: ecology, conservation and management in Europe. European Squirrel Initiative. Woodbridge Google Scholar, pp.67-82.

Selonen V, Varjonen R, Korpimäki E., 2015. Immediate or lagged responses of a red squirrel population to pulsed resources. Oecologia 177, 401-411.

Selonen, V., Varjonen, R., Korpimäki, E., 2016. Predator presence, but not food supplementation, affects forest red squirrels in winter. Annales Zoologici Fennici, 53, 183193.

Seto, K.C., Fragkian, M., Güneralp, B., Reuilly, K.M., 2011. A meta-analysis of global urban land expansions. Ploss One, 6,:e23777.

Shanahan, D.F., Strohbach, M.W., Warren, P.S., Fuller, R.A., 2014. The challenges of urban living. In: Gil, D., Brumm, H. (Eds), Avian Urban Ecology. Oxford University Press, Oxford, pp. 3-20.

Shar, S., Lkhagvasuren, D., Bertolino, S., Henttonen, H., Kryštufek, B., Meinig, H., 2008. Sciurus vulgaris. The IUCN Red List of Threatened Species 2008: e.T20025A9135609. http://dx.doi.org/10.2305/IUCN.UK.2008.RLTS.T20025A9135609.en. Downloaded on 28 January 2016.

Shochat, E., Warren, P.S., Faeth, S.H., McIntyre, N.E., Hope, D., 2006. From patterns to emerging processes in mechanistic urban ecology. Trends in ecology and evolution 21, 186191.

Shuttleworth, C.M., 2001. Traffic related mortality in a red squirrel (Sciurus vulgaris) population receiving supplemental feeding. Urban Ecosystems 5, 109-118.

Silvertown, J., 2009. A new dawn for citizen science. Trends in Ecology \& Evolution, 24, 467-471.

Siriwardena, G. M., Stevens, D. K., Anderson, G. Q., Vickery, J. A., Calbrade, N. A., Dodd, S. 2007. The effect of supplementary winter seed food on breeding populations of farmland birds: evidence from two large-scale experiments. Journal of Applied Ecology, 44, 920-932. Statistics Finland, 2015. Statistical Yearbook of Finland 2014. Helsinki.

Steele, M.A., 2008. Evolutionary interactions between tree squirrels and trees: A review and synthesis. Current Science 95, 871-876.

Sulkava, S., Lokki, H., Solonen, T., 2014. Kanahaukan pesimäaikainen ravinto kaupunkiympäristössä ja maaseudulla Etelä-Suomessa (Diet of the Northern Goshawk during the breeding season in urban and rural environments in Southern Finland). Suomen Riista 60, 20-30. (In Finnish, with English summary)

Tryjanowski, P., Skórka, P., Sparks, T.H., Biaduń, W., Brauze, T., Hetmański, T., Kawa, P., 2015. Urban and rural habitats differ in number and type of bird feeders and in bird species 
consuming supplementary food. Environmental Science and Pollution Research 22, 1509715103.

Uchida, K., Suzuki, K., Shimamoto, T., Yanagawa, H., Koizumi, I., 2015. Seasonal variation of flight initiation distance in Eurasian red squirrels in urban versus rural habitat. Journal of Zoology 298, 225-231.

Väisänen, R.A., 1999.Talvilintujen ruokintapaikoilla vierailevat petolinnut ja nisäkkäät (Occurrence of raptors, owls and mammals at feeding sites of winter birds in Finland). Linnut 34, 8-11. (in Finnish, with English summary)

Verboom B., van Apeldoorn R., 1990. Effects of habitat fragmentation on the red squirrel, Sciurus vulgaris L. Landscape Ecology 4, 171-176.

Verbeylen, G., De Bruyn, L., Adriaensen, F., Matthysen, E., 2003. Does matrix resistance influence Red squirrel (Sciurus vulgaris L. 1758) distribution in an urban landscape? Landscape ecology 18, 791-805.

UN, 2014. World urbanization prospects, the 2014 revision. Department of economic and social affairs, population division, New York.

Wauters, L. A., Somers, L., Dhondt, A., 1997. Settlement behaviour and population dynamics of reintroduced red squirrels Sciurus vulgaris in a park in Antwerp, Belgium. Biological Conservation 82, 101-107.

Wauters, L., Dhondt, A.A., 1992. Spacing behaviour of red squirrels, Sciurus vulgaris: variation between habitats and the sexes. Animal Behaviour 43, 297-311. Wilcox, B.A., Murphy, D.D., 1985. Conservation strategy: the effects of fragmentation on extinction. The American Naturalist 125, 879-887. 
Appendix 1. Relative abundances of red squirrels at Finnish survey sites (black circles; larger circles indicate higher abundances). X markings show sites where the species was not observed in counts. The red circles show the locations of the 20 largest cities in Finland. 


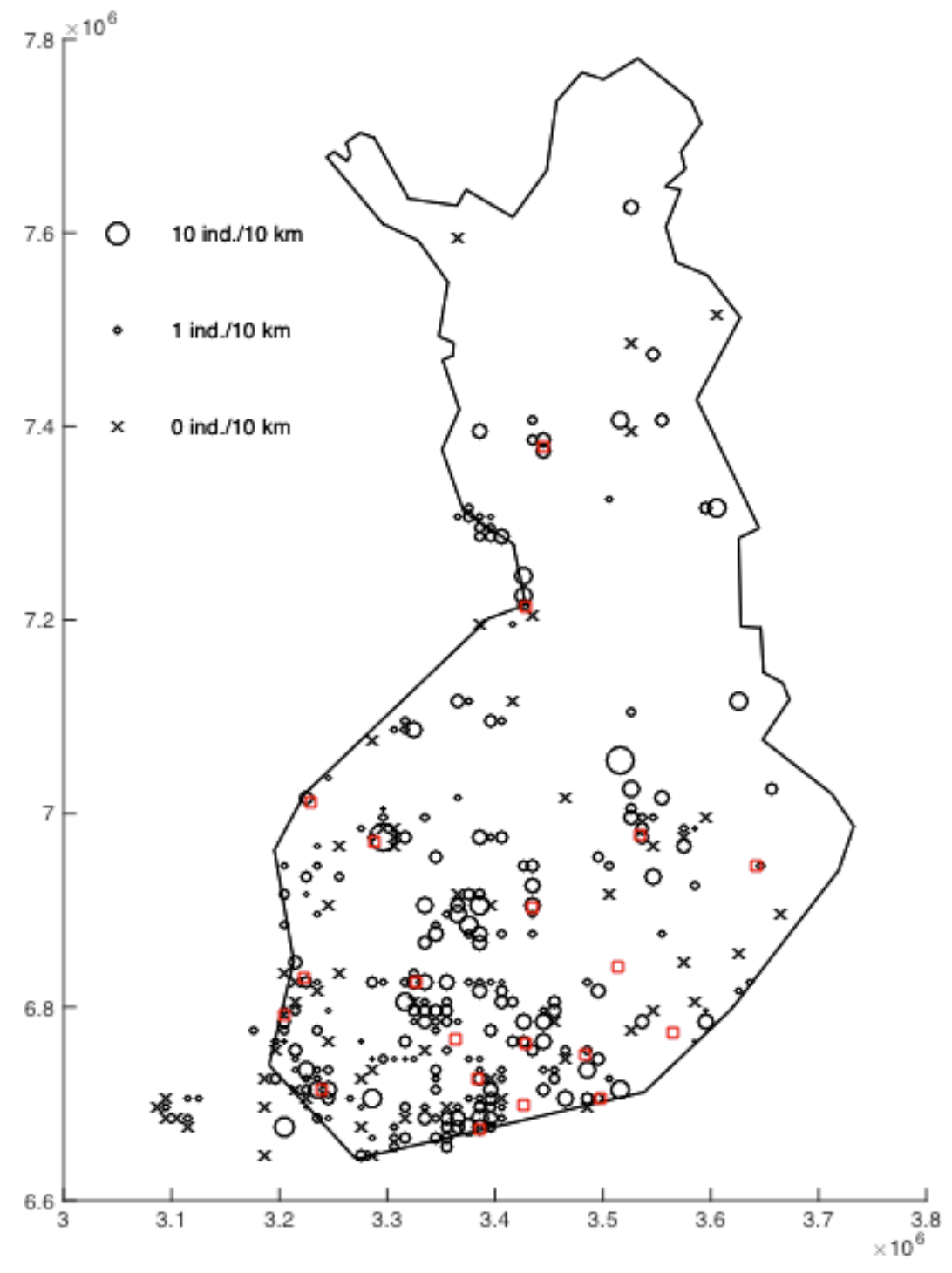


Figure legends:

Fig. 1. Relative squirrel abundance per transect route in relation to (A) human density (humans $/ \mathrm{km}^{2}$ ) and (B) abundance of feeding sites (feeding sites/transect route $\mathrm{km}$ ). Note the $\log$ scale of the x-axis.

Fig 2. Relative abundances of red squirrels (individuals per $10 \mathrm{~km}$ survey transect route) in relation to (A) different habitat types (dumping grounds, urban and rural areas, arable land, forest (trees $>5 \mathrm{~m}$ ), clear-cut areas and stands of saplings (trees $<5 \mathrm{~m}$ ), reed beds, shore scrub, and others), and (B) different spruce cone crop levels $(1=$ none, $2=$ very few, $3=$ few, $4=$ moderate, $5=$ abundant, 6 = very abundant (only three transect routes of these). 

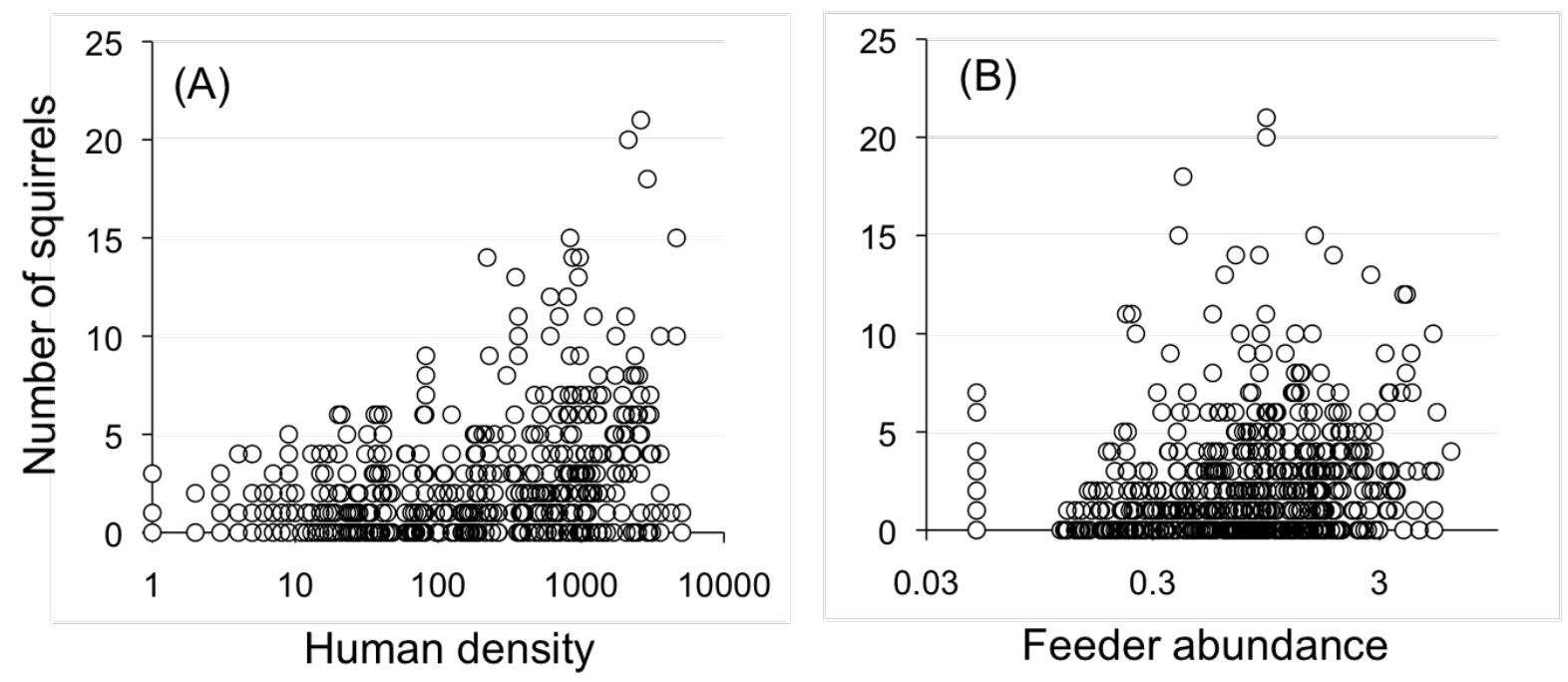

Jokimäki et al. Fig. 1.

Fig. 1. Relative squirrel abundance per transect route in relation to (A) human density (humans $/ \mathrm{km}^{2}$ ) and (B) abundance of feeding sites (feeding sites/transect route $\mathrm{km}$ ). Note the log scale of the $\mathrm{x}$-axis. 

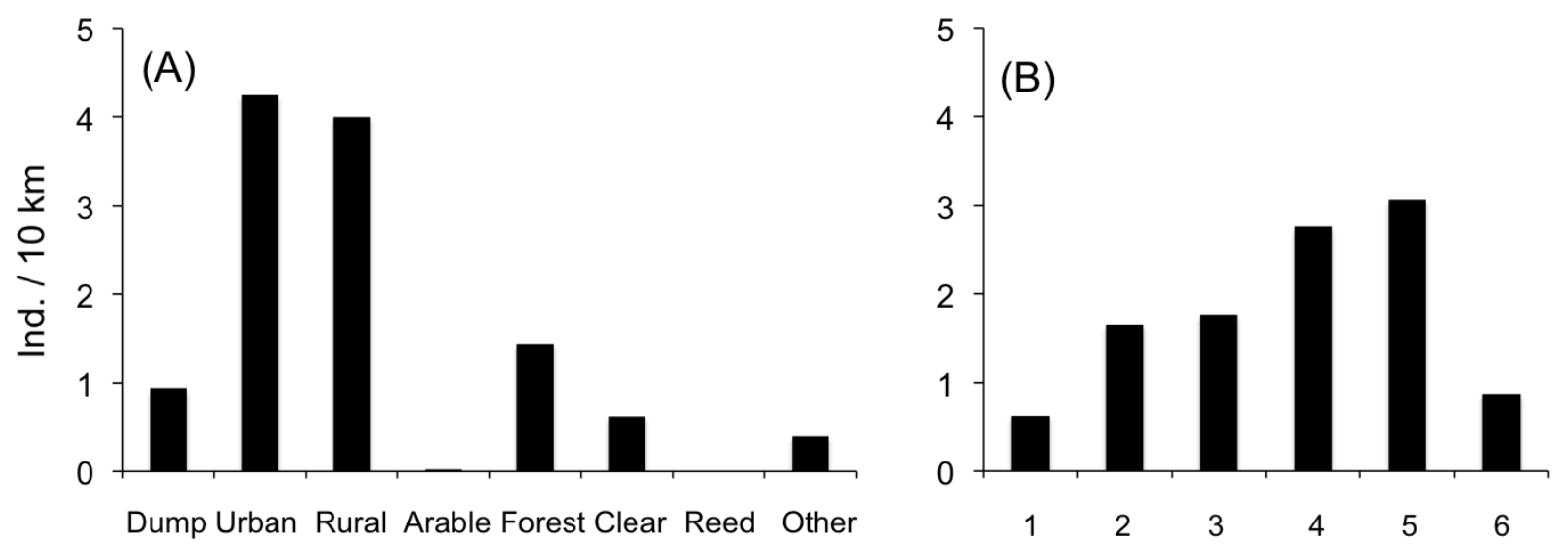

Jokimäki et al. Fig 2.

Fig 2. Relative abundances of red squirrels (individuals per $10 \mathrm{~km}$ survey transect route) in relation to (A) different habitat types (dumping grounds, urban and rural areas, arable land, forest (trees $>5 \mathrm{~m}$ ), clear-cut areas and stands of saplings (trees $<5 \mathrm{~m}$ ), reed beds, shore scrub, and others), and (B) different spruce cone crop levels $(1=$ none, $2=$ very few, $3=$ few, $4=$ moderate, $5=$ abundant, $6=$ very abundant (only three transect routes of these). 
Table 1. Relative squirrel abundance and number feeding sites in different habitats (and their lengths) surveyed during winter bird counts.

\begin{tabular}{|c|c|c|c|c|c|c|}
\hline & Squirrels & Feeders & Goshawks & Cats & & ers \\
\hline Forest & 403 & 203 & 75 & & 1 & 2812 \\
\hline Dump-land & 1 & 4 & 2 & & 0 & 11 \\
\hline Urban & 850 & 3657 & 115 & & 69 & 2003 \\
\hline Rural & 493 & 2399 & 28 & & 81 & 1233 \\
\hline Arable land & 2 & 23 & 26 & & 2 & 897 \\
\hline Clear-cut & 26 & 54 & 1 & & 0 & 421 \\
\hline Reed-bed & 0 & 4 & 7 & & 0 & 262 \\
\hline Other & 6 & 9 & 67 & & 29 & 150 \\
\hline
\end{tabular}


Table 2. Models explaining the transect route-specific abundance of squirrels in Finnish winter surveys, ranked based on the AIC. The AIC difference ( $\triangle \mathrm{AIC}), \mathrm{AIC}$ weight (w) and evidence ratio (E-rat) are shown. Transect route ID was used as a random factor in all models. Length is the length of the transect route. Lat and Lon are the latitude and longitude of the transect route, respectively. Season is the survey season. $\mathrm{H}$ and $\mathrm{H} 2$ are the log-transformed human density and its quadratic effect along the transect route, respectively. Hawk, Cat and Feed are the abundances of goshawks, cats and feeding sites, respectively. 


\begin{tabular}{|c|c|c|c|}
\hline Model & $\triangle \mathrm{AIC}$ & $\mathrm{w}$ & E-ratio \\
\hline Length + Lat + Lon + Season $+\mathrm{H} 2 * \mathrm{~F}+\mathrm{Cat}$ & 0.00 & 0.27 & 1.00 \\
\hline Length + Lat + Lon + Season $+\mathrm{H} 2 *$ Lat + Cat $+\mathrm{H} 2 * \mathrm{~F}$ & 1.82 & 0.11 & 2.48 \\
\hline Length + Lat + Lon + Season $+\mathrm{H} 2 * \mathrm{~F}+$ Hawk + Cat & 2.00 & 0.10 & 2.72 \\
\hline Length + Lat + Lon + Season $+\mathrm{H} 2 * \mathrm{~F}$ & 2.12 & 0.09 & 2.89 \\
\hline Length + Lat + Lon + Season + Cat $+\mathrm{H} 2+\mathrm{F}$ & 2.98 & 0.06 & 4.44 \\
\hline Length + Lat + Lon + Season + Cat $+\mathrm{H} 2$ & 3.82 & 0.04 & 6.75 \\
\hline Length + Lat + Lon + Season $+\mathrm{H} 2 *$ Lat + Hawk + Cat $+\mathrm{H} 2 * \mathrm{~F}$ & 3.82 & 0.04 & 6.75 \\
\hline Length + Lat + Lon + Season $+\mathrm{H} 2 *$ Lat $+\mathrm{H} 2 * \mathrm{~F}$ & 3.94 & 0.04 & 7.17 \\
\hline Length + Lat + Lon + Season $+\mathrm{H} 2 * \mathrm{~F}+$ Hawk & 4.12 & 0.03 & 7.85 \\
\hline Length + Lat + Lon + Season $+H 2 *$ Lat + Cat $+F$ & 4.60 & 0.03 & 9.97 \\
\hline Length + Lat + Lon + Season $+H^{*} \mathrm{~F}+$ Cat & 4.68 & 0.03 & 10.38 \\
\hline Length + Lat + Lon + Season $+\mathrm{H} 2+\mathrm{F}$ & 4.86 & 0.02 & 11.36 \\
\hline Length + Lat + Lon + Season + Hawk + Cat $+\mathrm{H} 2+F$ & 4.96 & 0.02 & 11.94 \\
\hline Length + Lat + Lon + Season $+\mathrm{H}+\mathrm{Cat}+\mathrm{F}$ & 5.80 & 0.01 & 18.17 \\
\hline Length + Lat + Lon + Season $+\mathrm{H} 2 *$ Lat + Hawk $+\mathrm{H} 2 * \mathrm{~F}$ & 5.94 & 0.01 & 19.49 \\
\hline
\end{tabular}




\begin{tabular}{|c|c|c|c|}
\hline Length + Lat + Lon + Season $+H 2 *$ Lat $+F$ & 6.50 & 0.01 & 25.79 \\
\hline Length + Lat + Lon + Season $+H^{*}$ Lat + Cat $+H * F$ & 6.56 & 0.01 & 26.58 \\
\hline Length + Lat + Lon + Season $+H 2 *$ Lat + Hawk + Cat $+F$ & 6.58 & 0.01 & 26.84 \\
\hline Length + Lat + Lon + Season $+H^{*} F$ & 6.62 & 0.01 & 27.39 \\
\hline Length + Lat + Lon + Season $+H^{*} \mathrm{~F}+$ Hawk + Cat & 6.64 & 0.01 & 27.66 \\
\hline Length + Lat + Lon + Season + Hawk $+\mathrm{H} 2+\mathrm{F}$ & 6.84 & 0.01 & 30.57 \\
\hline Length + Lat + Lon + Season $+H^{*}$ Lat + Cat $+F$ & 7.50 & 0.01 & 42.52 \\
\hline Length + Lat + Lon + Season $+H+F$ & 7.56 & 0.01 & 43.82 \\
\hline Length + Lat + Lon + Season $+\mathrm{H}+$ Hawk + Cat $+F$ & 7.80 & 0.01 & 49.40 \\
\hline Length + Lat + Lon + Season $+H 2 *$ Lat + Hawk $+F$ & 8.48 & 0.00 & 69.41 \\
\hline Length + Lat + Lon + Season $+H^{*}$ Lat $+H^{*} F$ & 8.50 & 0.00 & 70.11 \\
\hline Length + Lat + Lon + Season $+H^{*}$ Lat + Hawk + Cat $+H^{*} \mathrm{~F}$ & 8.52 & 0.00 & 70.81 \\
\hline Length + Lat + Lon + Season $+H^{*} F+$ Hawk & 8.56 & 0.00 & 72.24 \\
\hline Length + Lat + Lon + Season $+H^{*}$ Lat $+F$ & 9.28 & 0.00 & 103.54 \\
\hline Length + Lat + Lon + Season $+\mathrm{H}+$ Hawk $+\mathrm{F}$ & 9.54 & 0.00 & 117.92 \\
\hline Length + Lat + Lon + Season $+H^{*}$ Lat + Hawk $+H^{*} \mathrm{~F}$ & 10.46 & 0.00 & 186.79 \\
\hline
\end{tabular}




\begin{tabular}{|c|c|c|c|}
\hline Length + Lat + Lon + Season $+H$ & 49.08 & 0.00 & $>10000$ \\
\hline Length + Lat + Lon + Season $+\mathrm{H}+$ Cat & 49.42 & 0.00 & $>10000$ \\
\hline Length + Lat + Lon + Season $+H^{*}$ Lat & 50.84 & 0.00 & $>10000$ \\
\hline Length + Lat + Lon + Season $+\mathrm{H}+$ Hawk & 51.08 & 0.00 & $>10000$ \\
\hline Length + Lat + Lon + Season $+H^{*}$ Lat + Cat & 51.16 & 0.00 & $>10000$ \\
\hline Length + Lat + Lon + Season + H + Hawk + Cat & 51.42 & 0.00 & $>10000$ \\
\hline Length + Lat + Lon + Season $+H^{*}$ Lat + Hawk & 52.84 & 0.00 & $>10000$ \\
\hline Length + Lat + Lon + Season $+H^{*}$ Lat + Hawk & 52.84 & 0.00 & $>10000$ \\
\hline Length + Lat + Lon + Season $+H^{*}$ Lat + Hawk + Cat & 53.16 & 0.00 & $>10000$ \\
\hline Length + Lat + Lon + Season $+H^{*}$ Lat + Hawk + Cat & 53.16 & 0.00 & $>10000$ \\
\hline Length + Lat + Lon + Season $+\mathrm{H} 2$ & 53.80 & 0.00 & $>10000$ \\
\hline Length + Lat + Lon + Season $+H 2 *$ Lat & 55.44 & 0.00 & $>10000$ \\
\hline Length+Lat+Lon+Season+Hawk+H2 & 55.80 & 0.00 & $>10000$ \\
\hline Length + Lat + Lon + Season $+\mathrm{H} 2 *$ Lat + Cat & 55.86 & 0.00 & $>10000$ \\
\hline Length + Lat + Lon + Season + Hawk + Cat $+\mathrm{H} 2$ & 56.24 & 0.00 & $>10000$ \\
\hline Length + Lat + Lon + Season $+\mathrm{H} 2 *$ Lat + Hawk & 57.42 & 0.00 & $>10000$ \\
\hline
\end{tabular}




\begin{tabular}{lccc} 
Length+Lat+Lon+Season+H2*Lat+Hawk+Cat & 57.84 & 0.00 & $>10000$ \\
Length+Lat+Lon+Season+Cat+F & 70.62 & 0.00 & $>10000$ \\
Length+Lat+Lon+Season+F & 71.14 & 0.00 & $>10000$ \\
Length+Lat+Lon+Season+Hawk+Cat+F & 71.68 & 0.00 & $>10000$ \\
& & & \\
Length+Lat+Lon+Season+Hawk+F & 72.14 & 0.00 & $>10000$ \\
& 142.04 & 0.00 & $>10000$ \\
Length+Lat+Lon+Season & 143.18 & 0.00 & $>10000$ \\
Length+Lat+Lon+Season+Cat & 143.20 & 0.00 & $>10000$ \\
Length+Lat+Lon+Season+Hawk & 144.36 & 0.00 & $>10000$ \\
\hline Length+Lat+Lon+Season+Hawk+Cat & & & \\
\hline
\end{tabular}


Table 3. Parameter estimates and test values for variables explaining the transect route-specific abundances of red squirrels in Finland in winter surveys based on the top-ranked model.

Coefficients that differ significantly from zero are bolded and nearly significant values $(\mathrm{P}<0.1)$ are show in italic.

\begin{tabular}{|c|c|c|c|}
\hline Variable & $\mathrm{B} \pm \mathrm{SE}$ & $\mathrm{z}$ & $\mathrm{P}$ \\
\hline Intercept & $4.884 \pm 2.215$ & 2.21 & 0.0274 \\
\hline Length & $0.043 \pm 0.016$ & 2.66 & 0.0078 \\
\hline Latitude & $-0.008 \pm 0.003$ & -3.01 & 0.0026 \\
\hline Longitude & $0.002 \pm 0.005$ & 0.39 & 0.6986 \\
\hline Season, mid-winter & $-0.931 \pm 0.089$ & -10.48 & $<0.0001$ \\
\hline Season, late-winter & $-\mathbf{0 . 6 3 7} \pm \mathbf{0 . 0 0 3}$ & -7.48 & $<0.0001$ \\
\hline Human density^2 & $0.023 \pm 0.003$ & 7.36 & $<0.0001$ \\
\hline Feeding places & $0.662 \pm 0.111$ & 5.97 & $<0.0001$ \\
\hline Cat & $-2.253 \pm 1.161$ & -1.94 & 0.0522 \\
\hline Human density $2^{\wedge}$ Feeding places & $-0.006 \pm 0.003$ & -2.18 & 0.0290 \\
\hline
\end{tabular}


Table 4. Models explaining habitat-specific abundances of squirrels in Finnish winter surveys, ranked based on the AIC. AIC difference ( $\triangle \mathrm{AIC}), \mathrm{AIC}$ weight (w) and evidence ratio (E-rat) are shown. Transect route was used as a random factor in all models. Length is the length of the transect route section. Lat is the latitude of the transect route. Season is the survey season. Hab is the habitat category of the transect route section. Feed is the abundance of feeders in the transect route section. Spruce is the transect route-specific spruce cone crop abundance.

\begin{tabular}{lrrrr}
\hline Model & \multicolumn{1}{l}{$\Delta$ AIC } & w & E-rat \\
\hline Length+Lat+Season+Hab+Feed+Spruce & 0 & 0.997 & 1 \\
Length+Lat+Season+Hab+Feed & 11.90 & 0.003 & 363.8 \\
Length+Lat+Season*Hab+Feed+Spruce & 17.98 & 0 & 8022.5 \\
Length+Lat+Season+Hab+Spruce & 35.96 & 0 & $>10000$ \\
Length+Lat+Season+Hab & 49.06 & 0 & $>10000$ \\
Length+Lat+Season+Feed+Spruce & 612.52 & 0 & $>10000$ \\
Length+Lat+Season+Feed & 621.50 & 0 & $>10000$ \\
Length+Lat+Season+Spruce & 827.24 & 0 & $>10000$ \\
Length+Lat+Season & 840.38 & 0 & $>10000$ \\
& & & & \\
\hline
\end{tabular}


Table 5. Parameter estimates and test values for variables explaining the section-specific squirrel abundances in Finland based on the top-ranked model. Coefficients that differ significantly from zero are bolded.

\begin{tabular}{|c|c|c|c|c|}
\hline Variable & B & SE & Z-value & $\mathrm{P}$ \\
\hline Intercept & -0.56 & 1.65 & -0.34 & 0.735 \\
\hline Length (per 100m) & 0.01 & 0.00 & 6.70 & $<0.001$ \\
\hline Dumpland & -0.71 & 1.02 & -0.69 & 0.489 \\
\hline Urban settlements & 0.81 & 0.11 & 7.31 & $<0.001$ \\
\hline Rural settlements & 0.50 & 0.10 & 4.95 & $<0.001$ \\
\hline Arable land & -4.37 & 0.71 & -6.14 & $<0.001$ \\
\hline Clear-cut & -18.30 & 11.40 & -0.02 & 0.987 \\
\hline Reedbeds & -3.37 & 0.71 & -4.72 & $<0.001$ \\
\hline Other & -2.70 & 0.39 & -6.98 & $<0.001$ \\
\hline Feeders & 0.04 & 0.01 & 6.25 & $<0.001$ \\
\hline Spruce cones & 0.17 & 0.04 & 3.75 & $<0.001$ \\
\hline Season, mid-winter & -0.65 & 0.08 & -7.79 & $<0.001$ \\
\hline Season, late-winter & -0.41 & 0.08 & -4.97 & $<0.001$ \\
\hline
\end{tabular}


Latitude

$-0.00$

0.00

$-0.58$

0.562 